\title{
Importance of a Small Carnivorous Isopod in Energy Transfer
}

\author{
A. Shafir* and J. G. Field \\ Zoology Department and Institute of Oceanography, University of Cape Town, Rondebosch, South Africa
}

\begin{abstract}
The predatory isopod Cirolana imposita (Barnard) inhabits kelp holdfasts off the west coast of southern Africa. Its

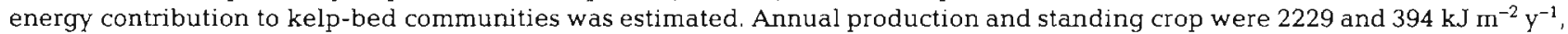
respectively $(P / B=5.56)$. Consumption (9899), defaecation (976) and respiration (1822) rates (kJ $\mathrm{m}^{-2} \mathrm{y}^{-1}$ ) were estimated experimentally and their relationships analyzed. The ratios between the various rates of energy transfer were used to characterize the physiological and ecological properties of the population. Assimilation efficiency ranged from $88-98 \%$ on a natural diet of syllid polychaetes, while gross growth efficiency, net growth efficiency and $P / R$ were calculated as $15-26 \%, 55 \%$ and 1.02, respectively. The ecological implications of the high assimilation efficiency and low metabolic rates combined with the various energy transfer components are discussed in relation to other members of the kelp-bed community. Although $C$. imposita biomass is less than half that of the commercially exploited rock-lobster Jasus lalandii, its energy-flow contribution to the community is estimated to be 5 times as great as the lobster's.
\end{abstract}

\section{INTRODUCTION}

Energy flow is one measure of the relative importance of components of an ecosystem. Energy flow need not be a limiting factor, nor is it necessarily the most important property of a population, as Kuenzler (1961) demonstrated in a mussel population which was more important as a phosphorus depositer than as an energy transferer. Nevertheless, energy flow is a fundamental dynamic property of ecosystems and most biological processes can, with reasonable convenience, be expressed in energy units.

This study was undertaken to assess the importance of an easily overlooked population of small Crustacea, compared with large obvious animals such as the rock lobster Jasus lalandii which is commercially exploited. The study area, a kelp-bed off the Cape Peninsula, South Africa, has been the site of community and ecosystem studies (Field et al., 1977; Velimirov et al., 1977; Field et al., in press) and several other component populations are subjects of continuing research. The population dynamics of Cirolana imposita (Barnard) are reported separately (Shafir and Field, in press); they show that two cohorts are produced annually and that most, if not all, females reproduce only

\footnotetext{
- Present address: The George S. Wise Centre for Life Sciences, Dept. of Zoology, Tel Aviv University, Tel Aviv, Israel
}

once while males live longer reaching a maximum lifespan of 2 years.

The literature contains a number of reports on the energetics of marine and freshwater primary-consumer invertebrates, exemplified by the studies of Richman (1958), Hughes (1970), Soldatova (1970), Paine (1971), Newell et al. (1977), Walz (1978), Griffiths and King (1979) and many others. Among primary-consumer isopods, studies have been carried out on: Idotea baltica and Sphaeroma pulchellum (Tsikhon-Lukania and Lukasteva, 1970), Tylos punctatus (Hayes, 1974), Asellus aquaticus (Prus, 1971, 1976) and Asellus racovitzai (Swiss and Johnson, 1976). The only detailed studies on energy flow in marine carnivores have been those by Paine (1965) on the opisthobranch mollusc Navanus inermis, Lasker (1966) on the zooplankter Euphausia pacifica, Shushkina et al. (1968) on Macrocyclops albidus, Sameoto (1972) on Sagitta elegans, Johnson (1976) on the intertidal isopod Cirolana harfordi, and Clarke (1979) on the Antarctic isopod Glyptonotus antarcticus.

The carnivorous family Cirolanidae is universally common on sandy beaches (Dahl, 1952, Johnson, 1976) but few species of the genus Cirolana have been reported to live predominantly on hard substrates subtidally (Jones, 1976). Cirolana imposita is found along the South African coast at depths from 2-200 m (B. Kensley, pers. comm.), and it is the commonest isopod 
found living in free space between the haptera of kelp holdfasts attached to rock on the west coast of South Africa (Shafir and Field, in press). Unfortunately the potential status of $C$. imposita as a top carnivore is still uncertain; it has not been identified in the gut contents of any potential predators nor have any animals been observed preying upon this isopod.

In this paper the conventional approach of energy flow analysis, based on the IBP formulation ( $C=P+R+F+U$ ), enables a check to be kept on energy partitioning within a population. Thus efficiency of energy turnover and the contribution of this particular population to the community are assessed.

\section{MATERIALS AND METHODS}

\section{Sampling}

The study area at Oudekraal $\left(34^{\circ} 00^{\prime} \mathrm{S}, 18^{\circ} 21^{\prime} \mathrm{E}\right)$ was confined to a kelp bed on a rock substrate at $12-16 \mathrm{~m}$ depth (Fig. 1). Sampling units consisting of Laminaria pallida holdfasts were collected by SCUBA diving and placed in separate plastic bags underwater after detaching them from the rock surface with a wide metal paint-scraper. In the laboratory the isopods were removed from holdfasts and their flattened body length measured from the telson tip to the anterior cephalon border. Measurements were made to the nearest millimeter under a binocular microscope. Specimens were grouped, sexed and the developmental state of the broods of ovigerous females was noted.

Preliminary observations, including plankton tows and clearing rock surfaces at different times of the day and night, established that Cirolana imposita is restricted to kelp holdfasts at the study site.

\section{Laboratory Measurements}

All the components of an energy budget are expressed in terms of calories or joules per unit time (1 $\mathrm{kcal}=4.18 \mathrm{~kJ}$ ). The calorific values for Cirolana imposita and for species of the polychaete genus Syllis (the food used in laboratory experiments) were determined with a Phillipson ballistic microbomb calorimeter following procedures outlined in the Gentry Instruments Inc. Manual. The samples were dried for $72 \mathrm{~h}$ at $60^{\circ} \mathrm{C}$ and then ground in a mill. This material was then dried at $60^{\circ} \mathrm{C}$ for $24 \mathrm{~h}$ until ignited in the bomb. Sample weights ranged from 5-15 mg for each determination. Duplicate samples were heated in a muffle furnace for $4 \mathrm{~h}$ at $500^{\circ} \mathrm{C}$, and the ash residue was compared to that left in the bomb as a check on complete combustion. When the ash content exceeded $30 \%$, corrections for calcium endothermy were applied (Paine, 1966).

Continuous changes in the proportion of ovigerous females in the population (Shafir and Field, in press) necessitated calculating length-weight regression curves periodically; 30-50 isopods were sub-sampled

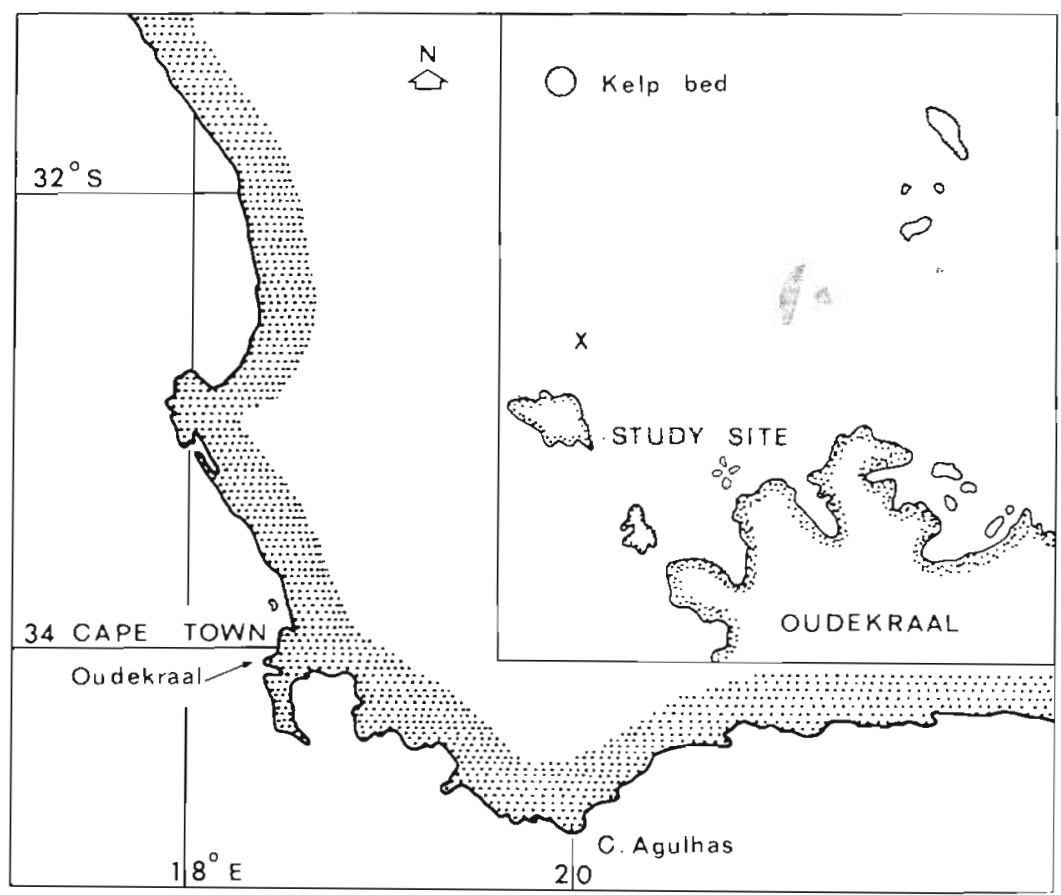

Fig. 1. Location of study site at Oudekraal, west coast of Cape Peninsula, South Africa. Shaded: areas colonized by kelp 
and measured on alternate months. Wet, dry and ashfree dry weight (AFDW) were determined while parallel sub-samples were treated with concentrated $\mathrm{HCl}$ (diluted 1:3) in order to decalcify them to give acidified dry weight. All separate and combined length-weight curves were fitted using least square regressions.

\section{Production and Standing Crop}

Production is calculated as the sum of energy produced as somatic tissue $(\mathrm{Pg})$ and reproductive material $(P r)$. Population production was calculated by the Allen curve method using slight smoothing modifications introduced by Peer (1970). Separate regressions for mortality and growth were fitted to data on numbers and mean weight (mg AFDW) respectively, against time. A smoothed Allen curve was constructed by reading points from the regressions at regular time intervals. Composite growth curves (Shafir and Field, in press) were used for the derivation of mean weight, and Allen curves were constructed by plotting the decreasing numbers $(N)$ against mean weight per individual of each cohort $(\vec{W})$, on the first day of every month (Shafir, 1978). Production $\left(P g+P_{r}\right)$ is given by the areas under the Allen curves. Reproductive effort was estimated independently as the product of the average fecundity per female (Shafir and Field, in press) and the average numbers of females with broods approaching release, in each monthly sample. Standing crop estimates were derived from the Allen curves by multiplying $N$ by $\bar{W}$ each month.

\section{Consumption, Egestion and Assimilation}

Examination of gut contents revealed that the main natural food items were polychaete worms of the family Syllidae. This was confirmed by preliminary feeding experiments. No feeding experiments were possible in the field owing to concealment of Cirolana imposita and its prey in the kelp holdfasts. Feeding experiments were carried out in the laboratory for periods of at least $50 \mathrm{~d}\left(\mathrm{t}{ }^{\circ} \mathrm{C}=13.1 \pm 1.3\right.$ S.D.; $\mathrm{S} \%=$ $35.8 \pm 0.9 ; \mathrm{pH}=7.96 \pm 0.15)$. Isopods were starved for 5 weeks before feeding in constant water flow compartments, each containing $7-10$ individuals of one size-class.

Food rations (syllid polychaetes) were at least double the amount eaten per day to avoid competition for food. Every week fresh food was added and all food remains and exuvia found were removed. Two compartments, one containing only unfed Cirolana imposita and, the other containing only syllids, served as controls. The amount of food consumed was recorded by weighing prey and remnants each day (blotted for 2 min to refnove excess water before weighing on a Mettler H20T balance). Faeces were separated from food using a dissecting microscope.

The formula of Klekowski and Duncan (1975) was applied:

$$
C=\frac{f-f_{n}}{t \cdot N}
$$

where $C=$ food consumption; $f=$ food offered; $f_{n}=$ food not eaten; $t=$ experimental time of measured feeding irrespective of feeding cycle; $N=$ numbers of consumer. The rate of food consumption was expressed as mg ash-free dry weight per $24 \mathrm{~h}$ for each size class of the population.

Defaecation rates were measured in two separate sets of experiments. While consumption was recorded faecal pellets were removed every second day. This operation did not affect food in the compartments due to the feeding habits of the isopods. The animals bolted down whole or large portions of syllids, thus the remains of the prey were easily distinguishable from the faecal pellets. In a second experiment, recently fed isopods were placed in $40 \mathrm{ml}$ Petri dishes containing filtered sea water (4 isopods of one size class in each dish). During the course of the experiment the isopods were not fed in order to determine the time for complete gut clearance $\left(t_{c}\right)$. Two dishes containing filtered sea water only were used as controls. Every second day the water was filtered using G.F.C.filter paper after which fresh filtered sea water was added. The filters were rinsed with an isoosmotic solution of ammonium formate (990 milliosmole) to remove salt, and dried in a drying oven at $60^{\circ} \mathrm{C}$ for $12 \mathrm{~h}$. Dry and ash-free dry weight were determined using a Mettler M30 electronic microbalance and ashing in a muffle furnace $\left(450^{\circ} \mathrm{C}\right.$ for $2 \mathrm{~h}$ ). The rate of faeces production is expressed as mg ash-free dry weight per $24 \mathrm{~h}$.

Assimilation efficiency was calculated by two methods, the wellknown Conover ratio (Conover, 1966) and a gravimetric method. The advantage of the Conover ratio method is that quantitative recovery of faeces is not required; a disadvantage is the assumption that only the organic fraction of food is absorbed. Several workers have queried this assumption (e. g. Prus, 1971; Tsikhon-Lukanina et al., 1968; hence a gravimetric method was also applied:

$$
A=\frac{C-F}{C} \times 100
$$

where $C=$ energy content of food ingested $\left(\mathrm{kJ} \mathrm{d}^{-1}\right) ; F$ $=$ energy content of faeces egested $\left(\mathrm{kJ} \mathrm{d}^{-1}\right) ; A=$ assimilation efficiency (\%). Data for these calculations were obtained from the feeding and egestion experiments. 
Gross growth efficiency (Richman, 1958) defined as growth/ingestion $\left(K_{1}\right)$ was measured in the laboratory and checked by similar calculations obtained indirectly from field data. Groups of $4-6,7-10$, and 10-12 mm Cirolana imposita were fed measured quantities of syllids for 3 months. The average increase in weight per isopod was noted at the end of the experiment.

$$
K_{1}=\frac{\triangle W}{C} \times 100
$$

where: $\triangle W=$ increase in weight on termination of experiment; $C=$ amount of food consumed during the course of the experiment.

\section{Respiration}

The population respiration of Cirolana imposita was estimated over a year. Every third month holdfasts were collected and transferred to the laboratory in sealed plastic bags after recording the temperature on the sea bed. Specimens covering the whole size range of the population were placed in the experimental vessels of a Gilson differential respirometer within 2 h of sampling. The guts of the isopods were checked to be full in order to rule out any differences that may result from previous feeding variations (Newell, 1979).

Isopods were acclimatized to ambient sea temperature for 12-16 h to minimize the effects of handling and temperature changes during transfer to the laboratory, factors to which Newell (1979) attributes elevated oxygen consumption, even in the absence of locomotory activity.

In the respirometer, measurements of oxygen consumption were carried out for periods lasting 28-32 h, using flasks with a central well containing $0.2 \mathrm{ml} 10 \%$ $\mathrm{KOH}$ and a scroll of filter paper to increase the surface area for $\mathrm{CO}_{2}$ absorption. A further flask containing $\mathrm{KOH}$ but not isopods was used as a control. Readings were taken at $1 \mathrm{~h}$ intervals. A total of 11-22 specimens were used in each experiment. S. T. P. correction factors were calculated for each separate experiment. On termination of the experiment specimens were measured. Log/log regressions of oxygen consumption versus ash-free dry weight were calculated by the least squares method. All possible paired combinations were compared using a $t$ test for the difference between two regression coefficients (Simpson et al., 1960).

Energy utilized in respiration by the Cirolana imposita population during 1976-77 was estimated using Sameoto's (1971) method. The densities of each 1-mm size class were taken from the data of Shafir and Field (in press). Oxygen consumed by all isopods in each size class in a given sample was calculated by converting length into $\mathrm{mg}$ ash-free dry weight (W), using the appropriate equation (Table 5). Monthly density data (Shafir and Field, in press) were used to calculate the total volume of oxygen respired by the population $\mathrm{d}^{-1}$, and converted to annual energy loss using the oxycalorific conversion of $20.18 \mathrm{~J}\left(\mathrm{ml} \mathrm{O} \mathrm{O}_{2}\right.$ respired) $)^{-1}$ (Hughes, 1970).

\section{RESULTS AND DISCUSSION}

The mean calorific value for Cirolana imposita (14.68 kJ g $\mathrm{kJ}^{-1} \mathrm{D}$. W.; $20.27 \mathrm{~kJ} \mathrm{~g}^{-1}$ AFDW) incorporates all the seasonal physiological, sexual and size variations presented by Shafir (1978) and summarized in Table 1 . This value is used in various energy-flow calculations.

The length/weight regression equations every second month were tested against one another (t-test, Simpson et al., 1960). Regression coefficients for February, May, August and October 1977 did not differ at the $5 \%$ level and were therefore combined to give the following curve:

$$
L=0.016 W^{2.66}\left(r^{2}=0.94, \mathrm{n}=149\right)
$$

where $L=$ body length in $\mathrm{mm} ; W=$ body weight in mg AFDW. Regression coefficients for December 1976 and December 1977 did not differ at the $5 \%$ level and their combined curve reads:

$$
L=0.004 W^{31.5}\left(r^{2}=0.96, \mathrm{n}=131\right)
$$

The regression coefficients of the two combined curves

\begin{tabular}{|c|c|c|c|c|c|c|}
\hline \multirow[t]{2}{*}{ Species } & \multirow[t]{2}{*}{ No. of observations } & \multirow[t]{2}{*}{$\%$ Ash } & \multicolumn{4}{|c|}{ Calorific values $\left(\mathrm{kJ} \mathrm{g}^{-1}\right)$} \\
\hline & & & Dry weight & $\mathrm{SD}$ & AFDW & $\mathrm{SD}$ \\
\hline \multicolumn{7}{|l|}{ (1) Cirolana imposita } \\
\hline a Mean of whole population & 35 & 27.23 & 14.62 & 1.67 & 20.27 & 2.70 \\
\hline b Eggs and larvae & 5 & 2.27 & 26.46 & 0.98 & 27.08 & 0.95 \\
\hline c Faeces & 2 & 18.05 & 9.96 & 0.36 & 12.26 & 0.30 \\
\hline (2) Syllis spp. & 7 & 22.50 & 18.34 & 5.09 & 24.04 & 1.09 \\
\hline
\end{tabular}
differ significantly at the $5 \%$ level.

Table 1. Cirolana imposita and Syllis spp. Calorific values and ash content. SD: Standard deviation; AFDW: ash-free dry weight 
Wet-, dry-, and ash-free dry weight regressions for the syllid polychaete food source yielded the following relationships:

$$
\begin{gathered}
\mathrm{DW}(\mathrm{mg})=0.578 \mathrm{WW}+0.00011 \\
(r=0.99, \mathrm{n}=50) \\
\mathrm{AFDW}(\mathrm{mg})=0.520 \mathrm{WW}+0.00017 \\
(r=0.99, \mathrm{n}=46)
\end{gathered}
$$

\section{Production and Standing Crop}

Allen curves of the five cohorts identified are shown in Figure 2. The dependence of the rate of production on the rate of body growth is demonstrated by annualproduction and standing-crop estimates for each cohort presented in Table 2. Cohort $C$ consisted of large (slow-growing) isopods. This is well reflected in its low production rate and large standing-crop values. Cohort $B$ had a big proportion of isopods in the fast-growing phase (5-7 $\mathrm{mm}$ in body length), thus high production is recorded. Most isopods in Cohort D were slow-growing juveniles $(2-5 \mathrm{~mm})$ and as a result production is low. Finally, Cohort A consisted of isopods which span almost the full size-range of the population, thus its production rate reflects all growth phases.

The amount of reproductive material produced annually $\left(P_{T}\right)$ is estimated to be $338 \mathrm{~kJ} \mathrm{~m}^{-2} \mathrm{y}^{-1}$, thus $P g$ $=P-P r=2229-338=1891 \mathrm{~kJ} \mathrm{~m}^{-2} \mathrm{y}^{-1}$.

The relatively high percentage of productive energy channelled into reproduction $(16.95 \%)$ is strongly supported by the fact that ovigerous females were present in samples throughout the year (Shafir and Field, in press). The energy contribution of exoskeletons is considered to be unimportant, and the isopods have been observed eating exuvia readily and regularly thus recycling a very small component of energy flow.

Shafir and Field (in press) have shown that the Cirolana imposita population produced 2 cohorts $\mathrm{y}^{-1}$. This is reflected in the standing crop variation in Figure 3. Standing crop showed three peaks and three troughs over the 18-month sampling period. Declining standing crop was caused by high juvenile mortality rates coupled with slow growth in the larger cohorts present (Shafir and Field, in press). The second and

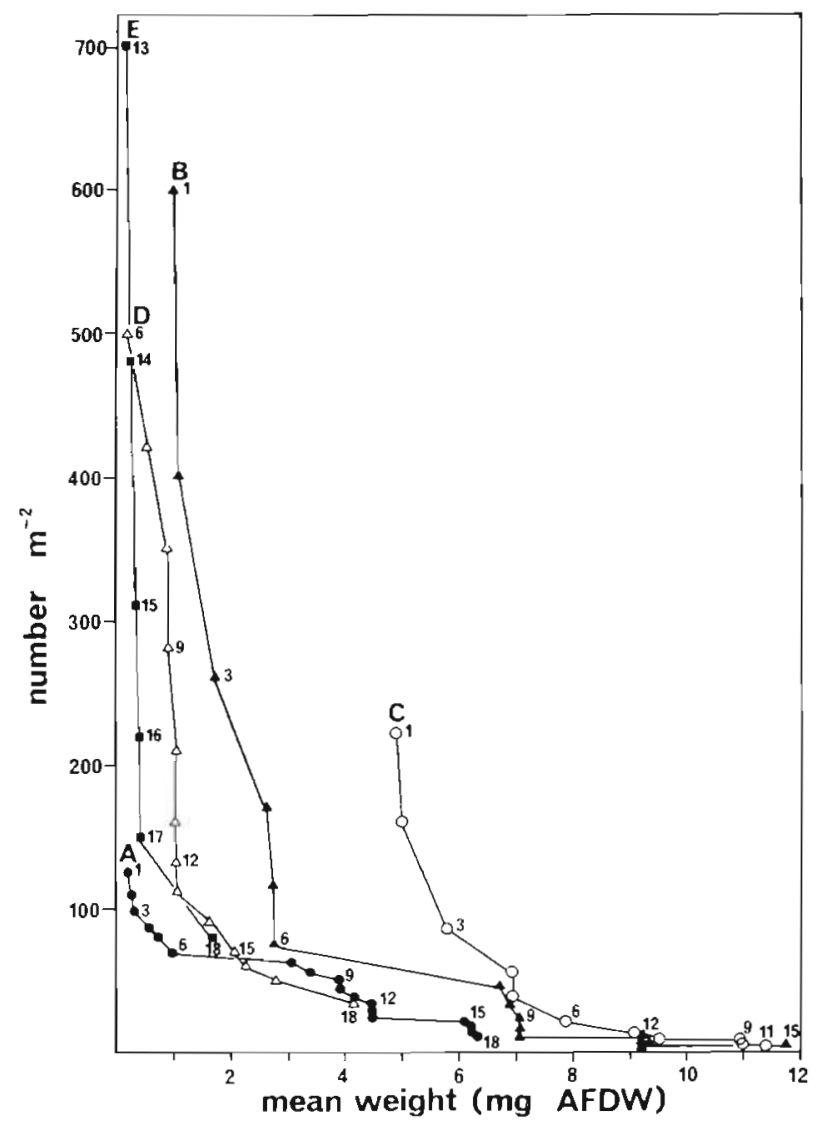

Fig. 2. Allen curves for cohorts A-E derived from density and growth data of Shafir and Field (in press); June 1976 (Month 1) - December 1977 (Month 18); numbers indicate sampling months

third declines were augmented by elimination of the oldest cohort in each case. Increases in standing crop occurred from November 1976-January 1977 (southern summer) and May-July 1977 (early winter), due in both cases to periods of rapid growth of 6 -month old cohorts which dominated the population.

The fluctuation pattern repeated itself during the sampling period, but standing crops in 1977 were slightly lower than corresponding values in 1976. Nevertheless, over the short sampling period the popu-

Table 2. Cirolana imposita. Production and standing crop estimates calculated from Allen curves for the period between June 1976 and May 1977

\begin{tabular}{|cccc|}
\hline Cohort & \multicolumn{2}{c|}{ Mean standing crop } & Annual production $\left(\mathrm{kJ} \mathrm{m}^{-2} \mathrm{y}^{-1}\right)$ \\
& $\left(\mathrm{g} \mathrm{m}^{-2}\right)$ & 47.84 & 571.83 \\
A & 2.37 & 109.34 & 810.45 \\
B & 5.41 & 204.86 & 508.36 \\
D & 10.14 & 32.27 & 338.40 \\
Population & 1.60 & $\bar{B}=394.31$ & $P=2229.03 \mathrm{~kJ} \mathrm{~m}^{-2} \mathrm{Y}^{-1}$ \\
\hline
\end{tabular}




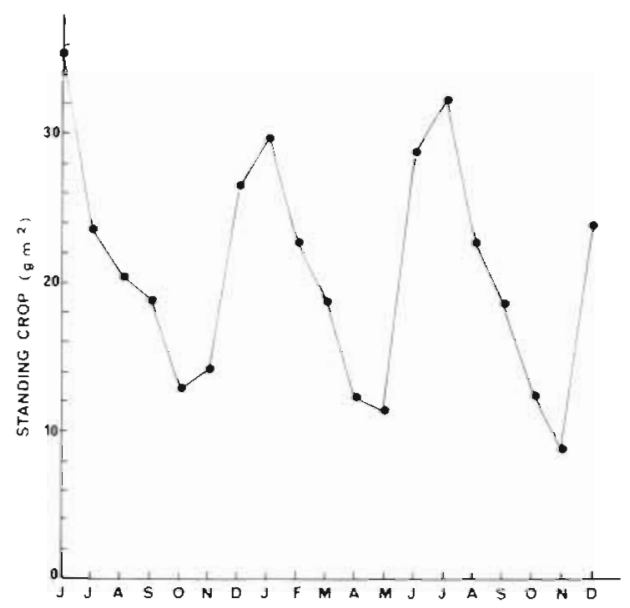

Fig. 3. Cirolana imposita. Fluctuations of mean standing crop of the population over a period of 18 months lation appeared to be remarkably stable. The mean standing crop for the year June 1976-June 1977 was $394.3 \mathrm{~kJ} \mathrm{~m}^{-2}$, giving a $P / \bar{B}$ ratio of 5.56 . This high turnover rate corresponds to fast growth rates recorded for this population by Shafir and Field (in press) and is at the top end of the range of $P / \bar{B}$ ratios reviewed by Warwick (in press), being particularly high for a population with a life span of 2 years, although the females do not live as long (Shafir and Field, in press).

\section{Consumption and Egestion}

Cirolana imposita, like many predatory arthropods, maintains a feeding-defaecation cycle which is typical of discontinuous periodic feeders (Klekowski and Duncan, 1975), with variable times of retention and considerable mixing of food in the gut (Shafir, 1978). Faeces

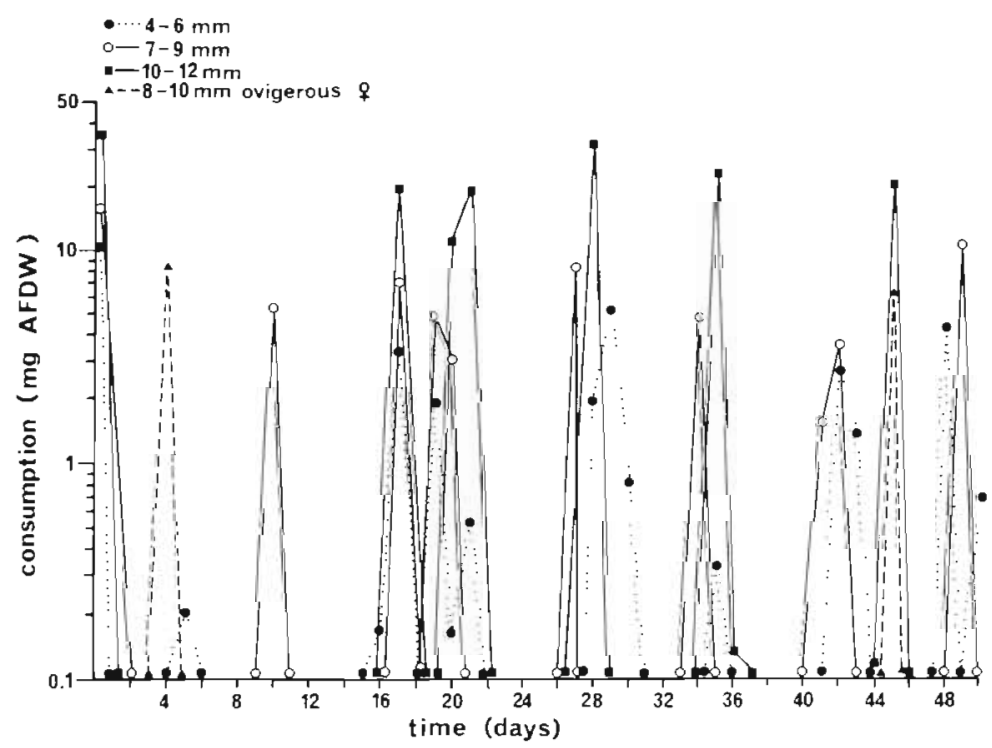

Fig. 4. Cirolana imposita. Food consumption ( $\mathrm{mg}$ AFDW ind. $\left.{ }^{-1} \mathrm{~d}^{-1}\right)$ in the laboratory. Juveniles $(4-6 \mathrm{~mm}$ length), adults $(7-9 \mathrm{~mm}$ $10-12 \mathrm{~mm})$, and ovigerous females $(8-10 \mathrm{~mm})$ are distinguished

Table 3. Cirolana imposita. Mean intake and egestion of food individual $24 \mathrm{~h}$. All data expressed as $\mathrm{mg}$ AFDW ind. $24 \mathrm{~h}^{-1} ; \mathrm{n}=$ number of observations

\begin{tabular}{|ccccccccc}
\hline $\begin{array}{c}\text { Body length } \\
\text { (mm) }\end{array}$ & $\mathrm{n}$ & $\begin{array}{c}\text { Mean food } \\
\text { uptake per } \\
\text { feeding } \\
\text { occasion }\end{array}$ & S.D. & $\begin{array}{c}\text { Mean daily } \\
\text { food uptake }\end{array}$ & S.D. & $\begin{array}{c}\text { Mean daily } \\
\text { faeces } \\
\text { production }\end{array}$ & S.D. & n \\
\hline $3-6$ & 35 & 2.23 & 1.26 & 0.16 & 0.11 & 0.032 & 0.03 & 35 \\
$6-8$ & 29 & 6.13 & 4.31 & 0.33 & 0.35 & 0.046 & 0.03 & 40 \\
$9-10$ & 33 & 8.66 & 6.85 & 0.39 & 0.37 & 0.046 & 0.03 & 50 \\
$11-12$ & 38 & 22.93 & 8.44 & 0.79 & 0.63 & 0.098 & 0.06 & 45 \\
$\begin{array}{c}\text { Ovigerous females } \\
(8-9)\end{array}$ & 25 & 7.26 & 1.49 & 0.07 & 0.12 & 0.05 & 0.03 & 25 \\
\hline
\end{tabular}




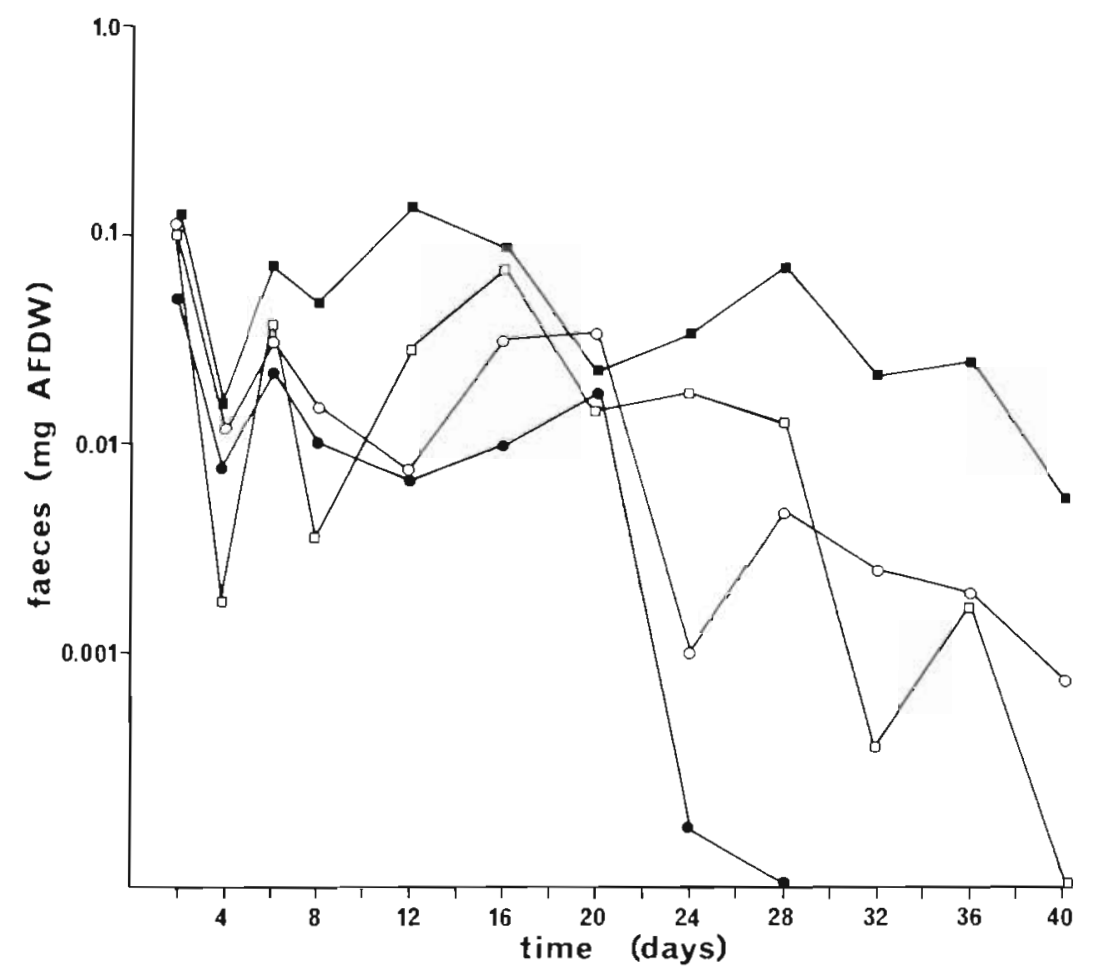

Fig. 5. Cirolana imposita. Faeces production (mg AFDW ind. ${ }^{-1} \mathrm{~d}^{-1}$ ) in the laboratory. Juveniles $(\bullet 3-5 \mathrm{~mm}$ ), adults $(\square 6-10 \mathrm{~mm}$; $11-12 \mathrm{~mm})$; ovigerous females (o $8-9 \mathrm{~mm}$ )

production at any one moment may originate from quite different feeding periods and one feeding interval may contribute to faeces egested at different times.

Figure 4 shows daily food consumption by Cirolana imposita in experiments lasting $50 \mathrm{~d}$. It suggests a marked feeding periodicity, differing in the various size groups of the population. Food was consumed discontinuously with a period of 1-2 weeks between two successive feeding intervals for specimens of 7-12 $\mathrm{mm}$ in body length. Juveniles fed more frequently but less regularly, whereas ovigerous females fed only twice during the course of the experiment with a time interval of $41 \mathrm{~d}$ between the two feeding occasions. When fed, ovigerous females consumed about half the quantity consumed by other adults of the same size (Fig. 4). Consumption is proportional to isopod size. The mean food intake per individual in $24 \mathrm{~h}$ is summarized in Table 3 . The large standard deviations are a direct result of the long time intervals between feeding bouts recorded in the experiments (Fig. 4). The daily feeding rate per individual as a function of animal weight (mg AFDW) is expressed in two power curves:

December-January: $\quad C=0.21 W^{050}\left(r^{2}=0.90, \mathrm{n}=20\right)$ February-November: $C=0.16 W^{0.59}\left(I^{2}=0.90, \mathrm{n}=20\right)$

Results of the feeding experiments are likely to lead to overestimates of natural feeding rates for three reasons: (1) the isopods were first starved in order to estimate egestion rates; (2) prey were probably more conspicuous in the experimental containers than in nature; (3) loss of prey body fluid upon capture was not accounted for. Nevertheless, only the third factor is likely to seriously affect the assimilation efficiency calculations.

Figure 5 shows the amount of faeces produced in egestion experiments lasting $40 \mathrm{~d}$. The amount of faeces produced was proportional to body size, excluding ovigerous females which produced considerably smaller quantities. The time of complete clearance of the gut $\left(t_{c l}\right)$ lasted 28 and $40 \mathrm{~d}$ for specimens of $3-5 \mathrm{~mm}$ and 6-10 $\mathrm{mm}$, respectively. On termination of the experiments, ovigerous females and isopods of 10-12 $\mathrm{mm}$ showed a considerable drop in faeces production (Fig. 5), but the exact $t_{c l}$ values could not be measured. The mean rate of faeces production is presented in Table 3 . The daily rates of faeces production per individual $(F)$ as a function of body weight ( $W$ in $\mathrm{mg}$ AFDW) is expressed by two equations:

December-January: $F=0.014 W^{0.24}\left(r^{2}=0.92, \mathrm{n}=62\right)$ February-November:

$$
F=0.012 W^{0.28}\left(r^{2}=0.92, \mathrm{n}=62\right)
$$

The egestion rate is a minimal estimate because only solid faeces were recovered, thus the amount of dissolved material leaching out was not accounted for.

Population estimates of energy ingested and egested were obtained using the above rate/weight equations applied to density and size-frequency data (sum- 
marized in Shafir and Field, in press) and the calorific consumption and egestion rates for each month were expressed as $\mathrm{kJ} \mathrm{m}^{-2} 24 \mathrm{~h}^{-1}$. These values were multiplied by the number of days in each month and summed to give estimates of annual consumption, $9899 \mathrm{~kJ}$ $\mathrm{m}^{-2} \mathrm{y}^{-1}$, and annual egestion, $977 \mathrm{~kJ} \mathrm{~m}^{-2} \mathrm{y}^{-1}$.

\section{Assimilation and Growth Efficiencies}

Assimilation efficiency is linearly related to body length:

$$
A=0.54 L+92.34 \quad(r=0.98, \mathrm{n}=40)
$$

where: $A=\%$ assimilation efficiency calculated gravimetrically; $L=$ body length in $\mathrm{mm}$.

The highest efficiencies recorded were those of ovigerous females (97.9\%), while females assimilated food slightly more efficiently than males $-94.2 \%$ and $91.4 \%$, respectively, for isopods $6-10 \mathrm{~mm}$ long. Ignoring differences due to sex and body size, the mean value obtained was $96.6 \%$ ( $\pm 1.63 \%$ S. D.) compared with a mean of $92.9 \%( \pm 1.25 \%)$ obtained by the Conover ratio.

Hubbell et al. (1965) have shown that gut clearance time is inversely related to feeding rate, thus a fast feeding rate forces food through the gut rapidly and assimilation efficiency is reduced. Table 3 shows a similar phenomenon in Cirolana imposita. Ovigerous fernales, handicapped morphologically by their brood pouches, consume little food and as a result food is retained in the gut for long periods and assimilation efficiency is the highest in the population.

The weight-specific feeding, egestion and assimilation equations for Cirolana imposita show that largest individuals consume and defaecate most per unit mass, yet assimilation efficiency is highest. This contradicts the general trend of decreasing assirnilation efficiency with increasing body weight (Tsikhon-Lukanina and Lukasteva 1970; Johnson, 1976; Greenwood, in press) but is not contrary to the pattern described by Hubbell et al. (1965). However, in C. imposita assimilation efficiency increases with size over only a narrow range $(89-98 \%)$ in comparison with other carnivorous invertebrates: $50-70 \%$ (Paine, 1965), 32-75\% (Ivleva, 1970), and with other isopods: 53-78\% (Hubbell et al., 1965), 51-86\% (Soldatova et al., 1969) and 26-46\% (Prus, 1971).

The assimilation efficiencies reported here are high but not exceptional for isopods (Hayes, 1974; Clarke, 1979) or for predatory invertebrates (Paine, 1965; Welch, 1968; Kozlovsky, 1968; Johnson, 1976). The mechanism whereby Cirolana imposita achieves high efficiency appears to be the elasticity of the hind gut. This enables them to fill their entire posterior body cavities in a short period of feeding, and then retain the food for periods of many days (Figs. 4, 5), allowing efficient digestion and assimilation. Kozlovsky (1968) concluded that assimilation rates of terrestrial and freshwater invertebrates are more efficient at progressively higher trophic levels. C. imposita fits this pattern, being at least a secondary carnivore since it feeds mainly on syllid polychaetes which are themselves carnivorous (J. H. Day, pers. comm.). Ivleva (1970) reports other carnivorous marine Crustacea with assimilation efficiencies mostly exceeding $90 \%$ and some reaching $99 \%$.

Table 4 summarizes laboratory growth efficiency experiments and shows gross efficiencies within the range reported for aquatic consumers by Welch (1968). With the exception of ovigerous females, $K_{1}$ decreases with increasing size following the regression:

$$
K_{1}=-1.97 L+35.95 \quad(r=0.94, \mathrm{n}=40)
$$

Thus small animals grow efficiently, agreeing with the fast juvenile growth reported in Shafir and Field (in press). Ovigerous females grow very little, but the small amount of food consumed by gravid females is channelled very efficiently into growth (Table 4).

\section{Respiration}

Figure 6 shows the mean oxygen consumption per individual $\left(\mathrm{VO}_{2}\right)$, averaged over the whole size range, at different times of year. It is apparent that respiratory activity was not affected by the length of the experiments, since peaks are similar at the start and end of

Table 4. Cirolana imposita. Average gross growth efficiencies of laboratory individuals belonging to various size classes. P: growth; $C$ : ingestion

\begin{tabular}{|cccccc|}
\hline Body length $(\mathrm{mm})$ & $\mathrm{n}$ & Time (months) & $P\left(\mathrm{~J} \mathrm{mg}^{-1}\right)$ & $C\left(\mathrm{~J} \mathrm{mg}^{-1}\right)$ & $(P / \mathrm{C}) \times 100$ \\
\hline $4-6$ & 24 & 3 & 171.7 & 677.0 & 25.36 \\
$7-9$ & 18 & 3 & 265.7 & 1172.0 & 22.67 \\
$7-10$ & 24 & 3 & 477.0 & 2495.0 & 18.83 \\
$9-12$ & 22 & 3 & 489.0 & 3380.0 & 14.46 \\
$\begin{array}{c}\text { Ovigerous females } \\
8-9\end{array}$ & 10 & 3 & 90.0 & 348.0 & 25.80 \\
\hline
\end{tabular}




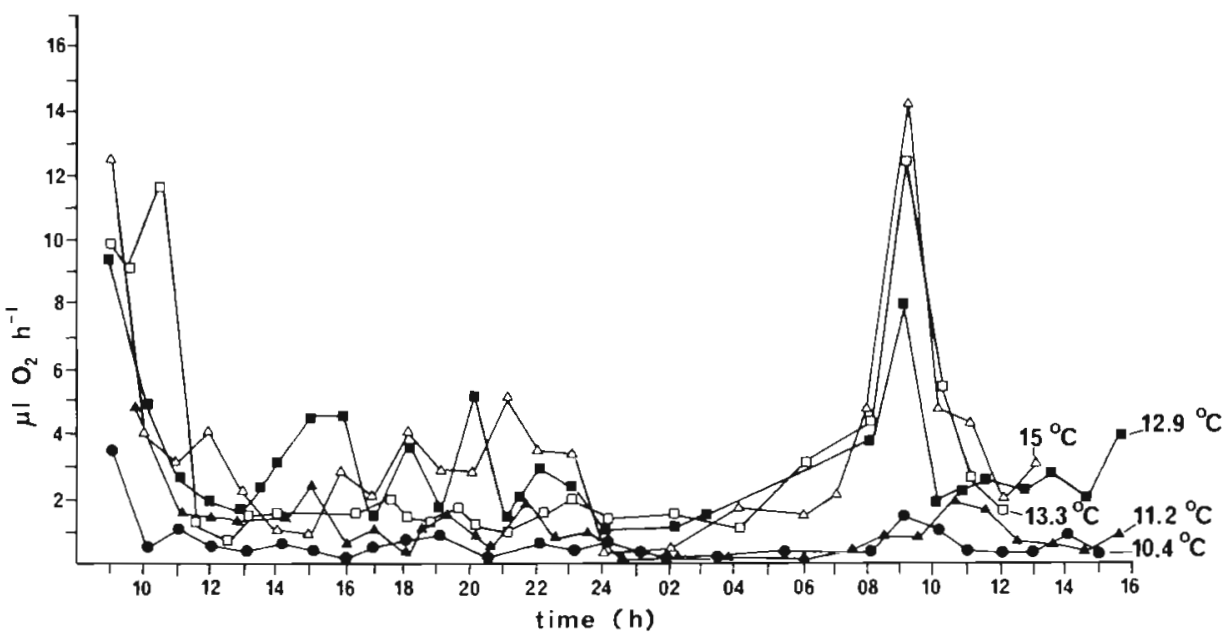

Fig. 6. Cirolana imposita. Mean oxygen consumption $\left(\mu \mathrm{l} \mathrm{O}_{2}\right.$ ind.$\left.^{-1} \mathrm{~h}^{-1}\right)$ of all experimental isopods at ambient temperature during 5 times of year, showing diumal variation

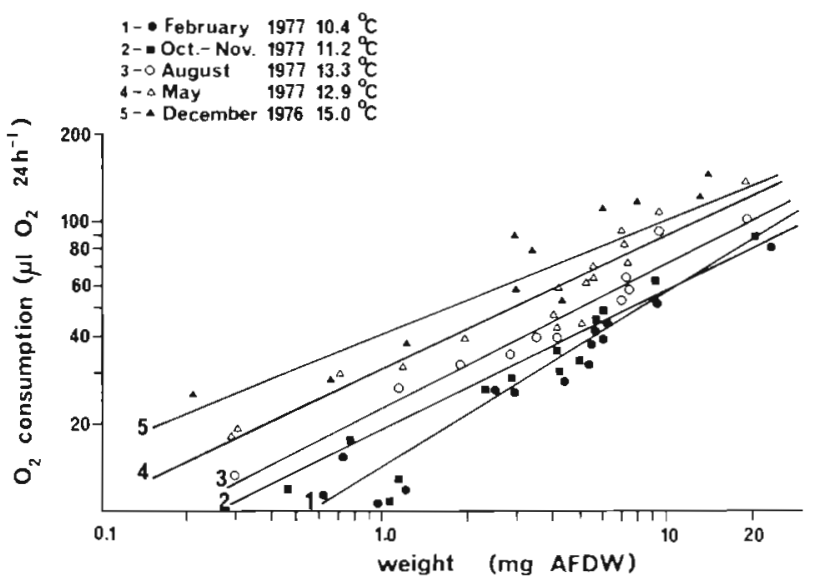

Fig. 7. Cirolana imposita. Oxygen consumption $\left(\mu \mathrm{O}_{2}\right.$ ind $^{-1}$ $\mathrm{d}^{-1}$ ) vs body size (mg AFDW); logarithmic scales. See Table 6 for equations

the experimental periods. Maximal ('active') rates are restricted to a brief period in the mornings (08:00-10:00) in a clear pattern. Smaller diurnal fluctuations represent 'routine' and 'standard' rates $(0-5 \mu \mathrm{l}$ $\mathrm{O}_{2}$ ind $^{-1} \mathrm{~h}^{-1}$ ) with an arbitrary division between the two. Nocturnal rates (24:00-04:00) show the lowest
$\mathrm{VO}_{2}$ values and can be defined as 'standard rate' in the activity pattern.

Figure 7 relates total daily oxygen consumption per individual to body weight at different seasons. The regression equations are given in Table 5. The slopes of Seasons 3,4 and 5 do not differ at the $5 \%$ level $(t$ tests; Simpson et al., 1960), nor do those of Seasons 1 and 2 . The slopes of these two groups of curves differ significantly from each other at the $5 \%$ level, but the intercept values for all 5 lines are not significantly different. The slope values are lower than the value applicable to aquatic Crustacea at $15^{\circ} \mathrm{C}$, but approach the value ( $b=0.67$ ) given by Wolvekamp and Waterman (1960) for Crustacea. Despite the fundamental relationship between metabolism and body size, there are many instances in which, for a particular species, the relationship may not apply (Newell and Pye, 1971). Table 5 indicates that the slopes show a trend with temperature and, despite the lack of statistically significant differences, the intercepts more than double from $10^{\circ}$ to $15^{\circ} \mathrm{C}$.

Figure 8 relates the oxygen consumption of a standard individual (derived from Fig. 7) to ambient temperature at different seasons. Oxygen uptake doubles

Table 5. Cirolana imposita. Respiration regressions for population at different times of year. Equations have the form log $\mathrm{VO}_{2}$ $\left(\mu \mathrm{IO}_{2}\right.$ ind. $\left.\mathrm{d}^{-1}\right)=\log a+b \log W(\mathrm{mg}$ AFDW $)$

\begin{tabular}{ccccccc|}
\hline Season & Date & Temperature $\left({ }^{\circ} \mathrm{C}\right)$ & $a$ & $b$ & $r^{2}$ \\
\hline 1 & 10.02 .77 & 10.4 & 12.10 & 0.67 & 0.97 & 15 \\
2 & 24.10 .77 & 11.2 & 13.07 & 0.66 & 0.95 & 11 \\
3 & 10.08 .77 & 13.3 & 22.37 & 0.49 & 0.89 & 11 \\
4 & 10.05 .77 & 12.9 & 30.64 & 0.46 & 0.94 & 13 \\
5 & 25.12 .77 & 15.0 & 39.03 & 0.45 & 0.84 & 12 \\
$1+2$ & Pooled & $10.4-11.2$ & 12.58 & 0.66 & 0.95 & 38 \\
$3,4,5$ & Pooled & $12.9-15.0$ & 31.60 & 0.48 & 0.89 & 34 \\
\hline
\end{tabular}




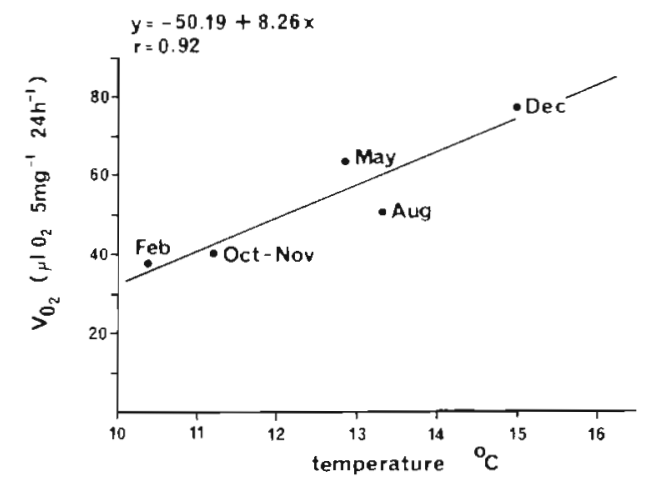

Fig. 8. Cirolana imposita. Weight-specific oxygen consumption $\left(\mu \mathrm{l} \mathrm{o}_{2} 5 \mathrm{mg}^{-1} \mathrm{~d}^{-1}\right)$ as a function of ambient temperature. $V O_{2}=-50.19+8.26 \mathrm{~T}\left({ }^{\circ} \mathrm{C}\right), r=0.92$

in the range $10.4^{\circ}-15.0^{\circ} \mathrm{C}\left(Q_{10}=4.5\right)$. Newell (1979) has shown that oxygen consumption of many active poikilotherms is more temperature dependent than that of the same animals in a quiescent state. Thus the very limited periods of activity in Cirolana imposita (Fig. 6) reduce to a minimum the extra energy expenditure due to elevated temperatures. Moreover, the limited temperature range at the study site (Velimirov et al., 1977) ensures that excessive energy expenditure is not incurred.

The unusually low metabolic rates recorded for Cirolana imposita are well supported by field observations. As a carnivore living in the restricted space and shelter of kelp holdfasts, C. imposita is able to maintain low levels of activity. This agrees with Wolvekamp and Waterman (1960) who state that benthic Crustacea spend most of their time in an inactive state interrupted by short periods of considerable activity when catching prey or avoiding predators. In contrast, the highest metabolic rates in Crustacea occur in small nearly continuously active forms like planktonic copepods. In $C$. imposita the annual energy loss due to population respiration is estimated to be $1822 \mathrm{~kJ} \mathrm{~m}^{-2}$ $\mathrm{y}^{-1}$.

\section{CONCLUSIONS}

Estimates of the partitioning of annual energy transfer through the Cirolana imposita population at Oudekraal can be summarized in the balanced energy equation for the period June 1976-May 1977: Consumption $(C)=$ Growth Production $\left(P_{g}\right)+$ Reproductive Production + Respiration $(R)$ and Faeces $(F)+$ Dissolved Losses (U)

$9899=1891+338+1822+977+U\left(\mathrm{~kJ} \mathrm{~m}^{-2} \mathrm{y}^{-1}\right)$.

In spite of feeding being one of the most direct processes linking trophic components in an ecosystem, estimates of consumption are the least developed of energy-transfer measurements. This is due to practical difficulties in both qualitative and quantitative studies of 'who eats whom' (Klekowski and Duncan, 1975). This study is no exception and field estimates of both consumption and egestion were not possible. Some workers have side stepped the problem by indirectly calculating consumption as the amount of food required to produce assimilation calculated as $(P+R) /$ $C$ (Sameoto, 1972; Johnson, 1976). This approach precludes independent comparison of the various energy budget components (Hughes, 1970; Hargrave, 1971; Paine, 1971\}. In spite of the error involved in extrapolating ingestion and egestion rates from laboratory experiments to the natural population (Sameoto, 1976), we agree with Klekowski and Duncan (1975) that the laboratory approach is justified when direct field measurements are not possible.

We have greater confidence in our estimates of production (since field and laboratory results agreed) and respiration rates, which appeared to follow a natural pattern in the respirometer (Fig. 6), although slightly lowered rates due to the absence of food cannot be ruled out. The imbalance in the energy budget can be attributed to three likely sources: overestimation of consumption, underestimation of egestion and the release of dissolved organic matter by secretion, excretion or from faeces or food during feeding. These last two possibilities would affect the estimates of egestion and consumption rates respectively. The lowest assimilation efficiency recorded for a marine carnivore is $74 \%$ (Sameoto, 1972). If this ratio is applied to increase the egestion estimate of the present budget, the gain of $1620 \mathrm{~kJ} \mathrm{~m}^{-2} \mathrm{y}^{-1}$ would account for only $33 \%$ of the discrepancy recorded. Urinary excretion in aquatic Crustacea is usually in the form of ammonia, and is thus likely to represent minimal energetic loss. It therefore seems probable that at least some of the imbalance has been caused by overestimation of consumption in feeding experiments.

Table 6 compares ecological efficiencies calculated for laboratory and energy budget estimates, showing good agreement. The net growth efficiency $\left(K_{2}\right)$ of 55 $\%$ is higher than average for marine carnivores which range from 20-60\% (Shushkina et al., 1968) or 20-90 $\%$ (Welch, 1968) and $K_{2}$ is generally negatively correlated with assimilation efficiency (Welch, 1968). Cirolana imposita has high $K_{2}$ and assimilation efficiencies, explicable in terms of its avoidance of respiratory losses by maintaining a low level of metabolism coupled with abundant prey. The $\log P$ : $\log R$ ratio of 1.03 is at the high end of the range reported in $\mathrm{McNeill}$ and Lawton (1970). Of 53 animals they report only 8 ( 7 insects, 1 decapod) with $\log P / \log$ $R$ greater than unity. All are poikilotherms with a lifespan of 2 years or less and resting stages with low 
Table 6. Cirolana imposita. Ecological efficiencies calculated for population from experimental and energy budget data

\begin{tabular}{|c|c|c|}
\hline Ratios & Range of experimental estimate & Energy budget estimate \\
\hline - Gross growth efficiency, $K_{1}=\frac{P \times 100}{C}$ & $15-26 \%$ & $23 \%$ \\
\hline Net growth efficiency, $K_{2}=\frac{P \times 100}{P+R}$ & - & $55 \%$ \\
\hline - Assimilation efficiency, $A=\frac{P+R}{C} \times 100$ & $88-98 \%$ & $90 \%$ \\
\hline
\end{tabular}

metabolic costs. C. imposita fits into this category, reflecting the short lifespan, fast growth, and low level of activity found. The annual turnover rate of the $C$. imposita population is high $(P / \bar{B}=5.56)$ reflecting the fast growth rates and small standing crop. A related species, $C$. harfordi, has a $P / \bar{B}$ ratio of 2.38 (Johnson, 1976).

Compared with other populations studied in the same system (Table 7), Cirolana imposita is seen to have higher growth and assimilation efficiencies in addition to a higher $P / R$ ratio and faster turnover times. Thus it is apparent that efficiencies increase as one progresses up the trophic ladder and that energy is utilized most efficiently in all phases of transfer by the C. imposita population. Field et al. (1977) have estimated the standing crop of the rock lobster Jasus lalandii to form $67 \%$ of that of all carnivores (Table 7 ). However, when one considers the energy available to potential predators, the productivity of $C$. imposita is $2229 \mathrm{~kJ} \mathrm{~m}^{-2} \mathrm{y}^{-1}$ in rocky areas of the study site, or 1583 $\mathrm{kJ} \mathrm{m} \mathrm{m}^{-2} \mathrm{y}^{-1}$ averaged over the whole 'offshore area' at Oudekraal. This is about 5 times the estimated production of Jasus lalandii (Field et al., 1977), the dominant carnivore in the system. Thus in terms of energy contribution a small inconspicuous carnivore with a fast turnover rate and high efficiencies of energy utilization appears to play a major role in the ecosystem.

Acknowledgements. We thank Dr. R. C. Newell and Dr. R. M. Warwick for criticizing the manuscript, and Mrs R. Griffiths and Miss M. Taswell for assistance with the figures and the manuscript. The work was supported by the kelp-bed research programme of the South African National Committee for Oceanographic Research and by the award of a Siri Johnson University of Cape Town bursary to the first-named author. The manuscript was completed at the NERC Institute for Marine Environmental Research, Plymouth, England.

Table 7. Comparison of energy utilization by different invertebrate populations in western Cape kelp beds. $\bar{B}$ : mean annual standing crop $\left(\mathrm{kJ} \mathrm{m}^{-2}\right)$ in habitat; $P$ : mean production in habitat $\left(\mathrm{kJ} \mathrm{m}^{-2} \mathrm{y}^{-1}\right) ; K_{1}$; gross growth efficiency; $K_{2}$ : net growth efficiency; $A$ : assimilation efficiency; $R$ : annual population respiration $\left(\mathrm{kJ} \mathrm{m}^{-2} \mathrm{y}^{-1}\right) ; C$ : annual population consumption $\left(\mathrm{kJ} \mathrm{m} \mathrm{m}^{-2} \mathrm{y}^{-1}\right)$

\begin{tabular}{|c|c|c|c|c|c|}
\hline Measurement/Ratio & $\begin{array}{l}\text { (1) } \\
\text { Parechinus } \\
\text { angulosus } \\
\text { (herbivore) }\end{array}$ & $\begin{array}{l}\text { Ligia dilatata } \\
\quad \text { (intertidal } \\
\text { detritus-feeder) }\end{array}$ & $\begin{array}{l}\text { (3) } \\
\text { Aulacomya ater } \\
\text { (suspension } \\
\text { feeder) }\end{array}$ & $\begin{array}{l}\text { (4) } \\
\text { Jasus lalandii } \\
\text { (scavenger- } \\
\text { carnivore) }\end{array}$ & $\begin{array}{c}\text { Cirolana } \\
\text { imposita } \\
\text { (camivore) }\end{array}$ \\
\hline $\bar{B}$ & 164.9 & 27.7 & 13390 & 1010 & 394 \\
\hline$P \quad P$ & 1708 & 69.2 & 15139 & $(400)^{\cdots}$ & 2229 \\
\hline$K_{1}=\frac{P}{C} \times 100$ & $5 \%$ & $0.8 \%$ & $(11 \%)^{\circ}$ & - & $15-26 \%$ \\
\hline$K_{2}=\frac{P}{P+R} \times 100$ & $23 \%$ & $17 \%$ & $(61 \%)^{*}$ & - & $55 \%$ \\
\hline$A=\frac{P+R}{C} \times 100$ & $69-73 \%$ & $5 \%$ & $(18 \%)^{*}$ & - & $88-98 \%$ \\
\hline $\log _{P / \bar{B}} P / \log R$ & $\begin{array}{l}0.35 \\
1.04\end{array}$ & $\begin{array}{l}0.81 \\
2.50\end{array}$ & $\begin{array}{l}1.26 \\
1.13\end{array}$ & ${ }_{(0.4)}^{-} \cdot$ & $\begin{array}{l}1.03 \\
5.56\end{array}$ \\
\hline \multicolumn{6}{|c|}{$\begin{array}{l}\text { (1) Greenwood (in press) } \\
\text { (2) Koop (1979) } \\
\text { (3) Griffiths and King }(1979)_{i} \cdot \text { estimate based on feeding experiments with Dunaliella } \\
\text { (4) Field et al. (1977); }{ }^{\prime} \text { estimated, final data not yet available }\end{array}$} \\
\hline
\end{tabular}




\section{LITERATURE CITED}

Clarke, A. (1979). Assimilation efficiency of the Antarctic isopod Glyptonotus antarcticus. Mar. Biol. 52: 157-160

Conover, R. J. (1966). Assimilation of organic matter by zooplankton. Limnol. Oceanogr. 11: 338-345

Dahl, E. (1952). Some aspects of the ecology and zonation of the fauna on sandy beaches. Oikos 4; 1-27

Field, J. G. Jarman, N. G., Dieckman, G. S., Griffiths, C. L., Velimirov, B., Zoutendyk, P. (1977). Sun, seaweeds, waves and lobsters: the dynamics of a west coast kelp bed. S. Afr. J. Sci. 73: 7-10

Field, J. G., Griffiths, C. L., Jarman, N. G., Zoutendyk, P., Velimirov, B., Bowes, A. (in press). Variations in structure and biomass of kelp communities along the west coast of South Africa. Trans R. Soc. S. Afr. 43

Greenwood, P. J. (in press). Growth, respiration and tentative energy budgets for two populations of the sea urchin Parechinus angulosus (Leske). Estuar. \& Coast. mar. Sci.

Griffiths, C. L., King, J. A. (1979). Some relationships between size, food availability and energy balance in the ribbed mussel Aulacomya ater. Mar. Biol. 51: 141-149

Hargrave, B. T. (1971). An energy budget for a deposit feeding Amphipod. Limnol. Oceanogr. 16: 99-103

Hayes, B. W. (1974). Sand beach energetics: importance of the Isopod Tylos punctatus. Ecology 55: 838-847

Hubbell, S. P., Sikora, A., Paris, O. H. (1965). Radiotracer gravimetric and calorimetric studies of ingestion and assimilation rates of an Isopod. Hlth Phys. 11: 1485-1501

Hughes, R. N. (1970). An energy budget for a tidal flat population of the Bivalve Scrobicularia plana. (Da Costa). J Anim. Ecol. 39: 352-381

Ivleva, I. V. (1970). The influence of temperature on the transformation of matter in marine invertebrates. In: Steele, J. H. (ed.) Marine food chains. University of California Press, Los Angeles, pp. 96-112

Johnson, W. S. (1976). Population energetics of the intertidal isopod Cirolana harfordi. Mar. Biol. 36: 351-357

Jones, D. A. (1976). The systematics and ecology of some isopods of the genus Cirolana (Cirolanidae) from the Indian Ocean region. J. Zool. Lond. 178: 209-222

Klekowski, R. A., Duncan, A. (1975). Feeding and nutrition. In: Grodzinski, W., Klekowski, R. Z., Duncan, A. (eds) Methods for ecological bioenergetics. Blackwell, Oxford, pp. 227-261 (IBP Handbook No. 24)

Koop, K. (1979). Biology and ecological energetics of the supralittoral isopod Ligia dilatata. M. Sc. thesis, Zoology Department, University of Cape Town, Rondebosch

Kozlovsky, D. G. (1968). A critical evaluation of the trophic level concept. I. ecological efficiencies. Ecology 49: 48-60

Kuenzler, E. J. (1961). Phosphorus budget of a mussel population. Limnol. Oceanogr. 6: 400-415

Lasker, $R$. (1966). Feeding, growth, respiration and carbon utilization of a Euphausid crustacean. J. Fish Res. Bd Can. 23: $1291-1317$

McNeill, S., Lawton, J. H. (1970). Annual production and respiration in animal population. Nature, Lond. 225: $472-474$

Newell, R. C. (1979). Biology of intertidal animals, 3rd ed., Marine Ecological Surveys Ltd., Faversham, Kent, U. K.

Newell, R. C., Pye, V I. (1971). Variations in the relationship between oxygen consumption, body size and summated tissue metabolism in the winkle Littorina littorea (L). J. mar biol. Ass. U. K. 51:-315-338

Newell, R. C., Johnson, L. G., Kofoed, L. M. (1977). Adjustment of the components of energy balance in response to temperature change in Ostrea edulis. Oecologia 30: $97-110$

Paine, R. T. (1965). Natural history limiting factors and energetics of the Opisthobranch Navanax inermis. Ecology 46: 603-619

Paine, R. T. (1966). Endothermy in bomb calorimetry. Limnol. Oceanogr. 11: 126-129

Paine, R. T. (1971). Energy flow in a natural population of the herbivorous Tugela funebralis. Limnol. Oceanogr. 16: 86-98

Peer, D. L. (1970). Relations between biomass productivity and loss to predators in a population of marine benthic polychaete, Pectinaria hyperborea. J. Fish Res. Bd Can. 27: $2143-2153$

Prus, T. (1971). The assimilation efficiency of Asellus aquaticus L. (Crustacea, Isopoda). Freshwat. Biol. 1: $287-305$

Prus, T (1976). Experimental and field studies on ecological energetics of Asellus aquaticus L. (Isopoda). II respiration at various temperatures as an element of energy budget. Ekologia Polska 24: 607-621

Richman, S. (1958). The transformation of energy by Daphnia pulex. Ecol. Monogr. 28: 275-291

Sameoto, D. D. (1971). Life history, ecological production, and an empirical mathematical model of a population Sagitta elegans in St. Margaret's Bay, Nova Scotia. J. Fish. Res. Bd Can. 28: 971-985

Sameoto, D. D. (1972). Yearly respiration rate and estimated energy budget for Sagitta elegans. J. Fish. Res. Bd Can. 29: $987-996$

Sameoto, D. D. (1976). Respiration rates, energy budgets, and molting frequencies of three species of Euphausids in the Gulf of St. Lawrence. J. Fish. Res. Bd Can. 33: 2568-2576

Shafir, A. (1978). Population dynamics and ecological energetics of the isopod Cirolana imposita in a kelp bed off the West Coast of South Africa. M. Sc. thesis, Zoology Department, University of Cape Town, Rondebosch

Shafir, A., Field, J. G. (in press). Population dynamics of the isopod Cirolana imposita (Crustacea: Malocostraca) in a kelp bed. Crustaceana

Shushkina, E. A., Anisimov, S. I., Klekowski, R. Z. (1968). Calculation of production efficiency in plankton copepods. Pal. Arch. Hydrobiol. 15: 251-261

Simpson, G. G., Roe, A., Lewontin, R. C. (1960). Quantitative zoology, Ilarcourt, New York

Soldatova, I. N. (1970). The energy balance of the amphipod Pontogammarus maeoticus. Oceanology 10: 129-138

Soldatova, I. N., Toikhon-Lukanina, Ye. A., Nikolayeva, G., Lukasteva, G. (1969). The conversion of food energy by marine crustaceans. Oceanology 9: 875-882

Swiss, J. J., Johnson, M. G. (1976) Energy dynamics of two benthic crustaceans in relation to diet. J. Fish Res. Bd Can. 33: $2544-2550$

Tsikhon-Lukanina, Ye A., Soldatova, I. N., Nikolayeva, G. G. (1968). Food assimilation by bottom crustacean of the Sea of Azov and methods for its determination. Oceanology 8: 388-393

Tsikhon-Lukanina, Ye A., Lukasteva, T. A. (1970). Conversion of food energy in the young of some marine isopods. Oceanology 10: 553-556

Velimirov, B., Field, J, G., Griffiths, C. L., Zoutendyk, P. (1977). The ecology of kelp communities in the Benguela upwelling system. Helgoländer wiss. Meeresunters. 30: 495-518

Walz, N. (1978). The energy balance of the freshwater mussel Dreissena polymorpha Pallas in the laboratory experiments and in Lake Constance. I. patterns of activity, feed- 
ing and assimilation efficiency. Arch. Hydrobiol. 55 (Suppl,): 83-105

Warwick, R. M. (in press). Population dynamics and secondary production of benthos. In: Tenore, K. R., Coull, B. C. (eds) Marine benthic dynamics. University of South Carolina Press, Columbia
Welch, H. E. (1968). Relationships between assimilation efficiencies and growth efficiencies for aquatic consumers. Ecology 49: 755-759

Wolverkamp, H. P., Waterman, T. H. (1960). Respiration. In: Waterman, T. H. (ed.) Physiology of Crustacea. Vol. I. Metabolism and growth. Academic Press, New York, pp. $35-100$

This paper was presented by Professor R. C. Newell; it was accepted for printing on June 4, 1980 